\title{
"MigRATION WITH DiGNITY": TOWARDS A NEW ZEALAND RESPONSE TO CLIMATE CHANGE DISPLACEMENT IN THE PACIFIC
}

\section{Harriet Farquhar*}

\begin{abstract}
The impacts of climate change threaten to cause the displacement of millions of people worldwide by the middle of this century. Despite this looming crisis, international law provides insufficient protection to those who will be forced to migrate. In most cases, those who are displaced will fall outside of current protection frameworks. This article examines why this protection deficit should be of particular concern to New Zealand, and argues that there are significant incentives for New Zealand to develop a response to the issue of climate change displacement in the Pacific. The article concludes that in order to ensure Pacific peoples are able to migrate with dignity, migration schemes which are pre-emptive and voluntary should be put in place to facilitate migration flows. These should build upon New Zealand's current immigration framework, and include the extension of current permanent and temporary migration schemes, as well as the introduction of labourtraining migration schemes.
\end{abstract}

\section{INTRODUCTION}

In its first Assessment Report in 1990, the Intergovernmental Panel on Climate Change (IPCC) warned that the "gravest effects of climate change may be those on human migration". ${ }^{1}$ Since this first Report, a wealth of evidence has emerged to support this projection, and in its most recent and comprehensive assessment of climate change to date, the IPCC states categorically that the longterm effects of climate change are expected to trigger large-scale population movements and

* Submitted as part of the LLB(Hons) programme at Victoria University of Wellington. Recipient of the Robert Orr McGechan Memorial Prize for Best Student Work for the Victoria University of Wellington Law Review. The author would like to thank Associate Professor Alberto Costi for all of his helpful comments and advice.

1 Intergovernmental Panel on Climate Change Policymakers' Summary of the Potential Impacts of Climate Change: Report from Working Group II to IPCC (Australian Government Publishing Service, 1990) at 20. 
significantly disrupt current migration flows. ${ }^{2}$ The world faces an impending displacement crisis. Increased frequency and severity of "climate events" such as storms, floods and droughts, as well as environmental degradation as a result of slow-onset "climate processes" such as sea-level rise, salination of agricultural land and water sources, desertification, and growing water scarcity, will lead to the displacement of millions of people. ${ }^{3}$ In fact, this has already begun. In 2012, an estimated 32.4 million people were displaced by natural disasters -98 per cent of which were climate and weather related events. ${ }^{4}$ Habitation in many parts of the world is becoming increasingly challenging.

Attempts to quantify the expected number of people who will be displaced by climate change "are fraught with numerous methodological problems and caveats". ${ }^{5}$ All estimates are based on unknown variables and assumptions regarding economic and social conditions, population growth, temperature increase, the rate at which climate change impacts will be felt, as well as the level of investment in mitigation and adaptation measures. ${ }^{6}$ The prediction most often repeated is that by 2050 between 200 and 250 million people will be displaced by climate change ${ }^{7}$ - approximately a five-fold increase over current numbers of documented refugees and internally displaced people. ${ }^{8}$ Other estimates vary from between 25 million to 1 billion climate migrants by $2050 .{ }^{9}$ This leaves no doubt that while the numbers are uncertain, the phenomenon is not. The disruption to current patterns of human settlement and migration as a result of climate change will be widespread and severe.

2 Intergovernmental Panel on Climate Change "Human Security" in Climate Change 2014: Impacts, Adaptation, and Vulnerability - Part A: Global and Sectoral Aspects (Cambridge University Press, Cambridge, 2014) 755 at 766 and $768-769$.

3 United Nations High Commissioner for Refugees The State of the World's Refugees: In Search of Solidarity: A Synthesis (2012) at 26.

4 Internal Displacement Monitoring Centre and the Norwegian Refugee Council Global Estimates 2012: People Displaced by Disasters (May 2013) at 6.

5 Frank Biermann and Ingrid Boas "Preparing for a Warmer World: Towards a Global Governance System to Protect Climate Refugees" (2010) 10 Global Environmental Politics 60 at 67.

6 Frank Biermann and Ingrid Boas "Protecting Climate Refugees: The Case for a Global Protocol" Environment Magazine (Washington, November/December 2008) at 10; and Jane McAdam "Environmental Migration Governance" (University of New South Wales Faculty of Law Research Series, No 2009-1, 2009) at 2 .

7 International Organization for Migration Climate Change, Migration and Critical International Security Considerations (2011) at 9.

8 As at 1 December 2014, the United Nations High Commissioner for Refugees (UNHCR) estimated that there are 11.7 million refugees worldwide and 23.9 million internally displaced people: United Nations High Commissioner for Refugees UNHCR Global Appeal 2015: Populations of Concern to UNHCR (December 2014).

9 United Nations High Commissioner for Refugees, above n 3, at 26. 
Despite this looming crisis, international law provides insufficient protection to those who are displaced by climate change. In most cases, those who are forced to relocate will not fall within current protection frameworks. This gap at international law should be of particular concern to New Zealand, which is likely to face increasing migration demands from neighbouring Pacific Island countries and territories (PICTs) - nations which are particularly vulnerable to the impacts of climate change and where levels of out-migration are likely to be high. This creates a considerable incentive for New Zealand to begin to examine possible responses to this issue.

The purpose of this article is to examine the case for New Zealand action on the issue of climate change displacement in the Pacific and to present possible policy responses. It argues that in order to ensure "migration with dignity", ${ }^{10}$ a New Zealand approach to climate change displacement should focus on the implementation of pre-emptive, voluntary migration schemes to increase mobility in the Pacific. This article concludes that these schemes should build upon New Zealand's existing immigration framework and include the expansion of permanent and temporary migration schemes, as well as the implementation of labour-training programmes aimed at Pacific peoples.

The discussion will proceed first by outlining the current lack of protection at international law. Secondly, it will examine why this lack of protection is of particular concern to New Zealand, and the case for New Zealand action on the issue. It will then discuss the general shape which a New Zealand policy response should take. Finally, substantive policy recommendations will be provided.

\section{THE INTERNATIONAL LEGAL FRAMEWORK}

The international legal regime grants only marginal protection to those who are displaced by climate change. This protection deficit has been the subject of considerable attention in legal scholarship, ${ }^{11}$ reports by international institutions and non-governmental organisations, ${ }^{12}$ and

10 Office of the President, Republic of Kiribati "Relocation" Kiribati Climate Change <www.climate.gov.ki>

11 See for example Jane McAdam Climate Change, Forced Migration and International Law (Oxford University Press, Oxford, 2012); Biermann and Boas, above n 5; Maxine Burkett "In Search of Refuge: Pacific Islands, Climate-Induced Migration, and the Legal Frontier" Asia Pacific Issues (No 98, East West Centre, Honolulu, January 2011); Benoit Mayer "Constructing 'Climate Migration' as a Global Governance Issue: Essential Flaws in the Contemporary Literature" (2013) 9 McGill International Journal of Sustainable Development Law and Policy 87; David Hodgkinson and others "'The Hour when the Ship Comes In': A Convention for Persons Displaced by Climate Change" (2010) 36 Mon LR 69; and Bonnie Docherty and Tyler Giannini "Confronting a Rising Tide: A Proposal for a Convention on Climate Change Refugees" (2009) 33 Harv Envtl L Rev 349.

12 See for example International Organization for Migration, above n 7; United Nations Refugee Agency UNHCR, the Environment and Climate Change: An Overview (September 2014); United Nations Office for the Coordination of Humanitarian Affairs, Internal Displacement Monitoring Centre and the Norwegian Refugee Council Monitoring Disaster Displacement in the Context of Climate Change: Findings of a Study by the United Nations Office for the Coordination of Humanitarian Affairs and the Internal Displacement Monitoring Centre (September 2009); and Asian Development Bank Addressing Climate Change and Migration in Asia and the Pacific: Final Report (2012). 
international and regional fora, ${ }^{13}$ and it is now well accepted that in most cases, those who are displaced by climate change will be unable to gain protection either under the Convention Relating to the Status of Refugees $1951^{14}$ ("the Refugee Convention") or complementary protection measures at international law. There is also no protection afforded under the United Nations Framework Convention on Climate Change ${ }^{15}$ (UNFCCC) or at a regional level in the Pacific, and there is no established "responsibility to protect" in cases of environmental disaster.

This position has been confirmed in the New Zealand context in recent judicial decisions by the Immigration and Protection Tribunal (IPT) in $A F$ (Kiribati), ${ }^{16}$ upheld on appeal by both the High Court and Court of Appeal in Teitiota $v$ The Chief Executive of the Ministry of Business, Innovation and Employment (Teitiota), ${ }^{17}$ and in $A D$ (Tuvalu). ${ }^{18}$ In Teitiota, the applicant was a citizen of Kiribati seeking protection in New Zealand on the basis of rising sea levels and environmental degradation, as a result of climate change in Kiribati. ${ }^{19}$ The IPT, High Court and Court of Appeal accepted the evidence presented by the applicant of the impacts of climate change on Kiribati storm surges, extreme high spring tides, flooding of residential areas, raised floors of residences, depletion of fishing stocks, diminution of arable land, contamination of drinking water by salt water, sewage contamination of water tables and deterioration of the population's health. ${ }^{20}$ Nevertheless, the application was rejected in all three decisions. It was found that the applicant could gain neither refugee status nor protected person status in New Zealand. At the time of writing, the applicant had been granted leave to appeal to the Supreme Court. ${ }^{21}$ In $A D$ (Tuvalu), the IPT used its discretionary powers to overturn a deportation order in respect of a Tuvaluan family on humanitarian grounds. Although the application in this case was successful, $A D$ (Tuvalu) demonstrates that while climate

13 See for example United Nations Framework Convention on Climate Change - Conference of the Parties; and the Pacific Islands Forum.

14 Convention Relating to the Status of Refugees 189 UNTS 137 (opened for signature 28 July 1951, entered into force 22 April 1954).

15 United Nations Framework Convention on Climate Change 1771 UNTS 107 (opened for signature 9 May 1992, entered into force 21 March 1994).

16 AF (Kiribati) [2013] NZIPT 800413.

17 Teitiota $v$ The Chief Executive of the Ministry of Business, Innovation and Employment [2013] NZHC 3125, [2014] NZAR 162 [Teitiota NZHC]; and Teitiota $v$ The Chief Executive of the Ministry of Business, Innovation and Employment [2014] NZCA 173, [2014] NZAR 688 [Teitiota NZCA].

18 AD (Tuvalu) [2014] NZIPT 501370 and [2014] NZIPT 501371.

19 Teitiota NZHC, above n 17, at [15].

20 At [18].

21 "Climate refugee takes fight to Supreme Court" (1 February 2015) Radio New Zealand <www.radionz.co.nz>; and "Supreme Court - Case Summaries 2015" (9 February 2015) Courts of New Zealand <courtsofnz.govt.nz>. 
change may be a factor which will be considered in determining whether such an order should be overturned, the impacts of climate change alone will not be sufficient.

\section{A Refugee Status, Complementary Protection and Humanitarian Grounds}

It is clear that in most cases, those who are displaced by climate change will not be able to seek protection under the refugee or complementary protection frameworks.

\section{Convention Relating to the Status of Refugees 1951}

A person is a refugee for the purposes of the Refugee Convention and its 1967 Protocol, ${ }^{22}$ who: ${ }^{23}$

... owing to well-founded fear of being persecuted for reasons of race, religion, nationality, membership of a particular social group or political opinion, is outside the country of his nationality, and is unable or, owing to such fear, is unwilling to avail himself of the protection of that country.

There are a number of obstacles to people displaced by climate change gaining protection under the Refugee Convention. First, there is significant difficulty in characterising climate change as "persecution", which requires an element of human agency. ${ }^{24}$ Secondly, even if it were accepted that climate change was a form of "persecution", the indiscriminate nature of its impacts precludes this persecution occurring on the basis of one of the five Convention grounds: race, religion, nationality, membership of a particular social group or political opinion. ${ }^{25}$ Finally, many people displaced by climate change are also likely to still be within their home country when seeking protection. ${ }^{26}$ Therefore, while those who are displaced by climate change are not expressly precluded from gaining refugee status, an applicant would need to prove that an additional element constituting persecution on one of the Convention grounds was present. ${ }^{27}$

The decisions of the IPT, High Court and Court of Appeal in Teitiota confirm this analysis, with the High Court decision being the most comprehensive. The Refugee Convention definition of a "refugee" is incorporated into domestic legislation under s 129(1) of the Immigration Act 2009,

22 Protocol Relating to the Status of Refugees 606 UNTS 267 (adopted 31 January 1967, entered into force 4 October 1967).

23 Convention Relating to the Status of Refugees, above n 14, art 1A(2).

24 McAdam, above n 11, at 43; McAdam, above n 6, at 12; and Robert McLeman "Climate Change Migration, Refugee Protection, and Adaptive Capacity-Building" (2008) 4 McGill International Journal of Sustainable Development Law and Policy 1 at 14.

25 McAdam, above n 11, at 44; and McAdam, above n 6, at 48.

26 McAdam, above n 11, at 43; and McAdam, above n 6, at 13.

27 McAdam, above n 11, at 44. 
which requires that "a person must be recognised as a refugee ... if he or she is a refugee within the meaning of the Refugee Convention". The IPT and the courts found that while the term "refugee" may be used in the political realm to refer to those displaced by natural disasters or climate change, "it is abundantly clear that displacement of such refugees has not been caused by persecution" and, therefore, does not fall within the definition provided by the Refugee Convention. ${ }^{28}$ It was noted that while "persecution" is not defined in the Convention, New Zealand has adopted a "human rights" approach, necessitating "the sustained or systematic violation of basic human rights demonstrative of a failure of state protection". ${ }^{29}$ Human agency is, therefore, required. In addition, the High Court found that it could not be said that people displaced by climate change had "become refugees ... on one of the five stipulated Refugee Convention grounds" ${ }^{30}$

The High Court emphasised, however, that because there is "a complex inter-relationship between natural disasters, environmental degradation and human vulnerability", this does not mean that environmental degradation can never provide pathways into the Convention. ${ }^{31}$ It may, for example, where environmental degradation leads to armed conflict or where humanitarian relief becomes politicised, and persecution on one of the five Convention grounds becomes present. ${ }^{32}$ Those displaced by reason of climate change alone, however, cannot obtain protection under the Refugee Convention. ${ }^{33}$

\section{Complementary protection}

Complementary protection, which precludes the non-refoulement of people who would be at risk of persecution, torture, cruel, inhuman or degrading treatment or punishment and arbitrary threats to life, has also been raised as a possible ground of protection for those displaced by climate change. ${ }^{34}$ Again, there is no express preclusion stopping those who have been displaced by climate change from gaining protection under this ground. However, courts have been careful to delimit these terms, and according to current jurisprudence the impacts of climate change alone cannot be considered "cruel or degrading treatment". ${ }^{35}$

28 Teitiota NZHC, above n 17, at [11].

29 At [8].

30 At [11].

31 At [27].

32 At [27].

33 At [26].

34 McAdam, above n 6, at 18.

35 McAdam, above n 11, at 54; and Jane McAdam and Ben Saul "Displacement with Dignity: International Law and Policy Responses to Climate Change Migration and Security in Bangladesh" (University of New South Wales Faculty of Law Research Series, 10/113, 2010) at 24. 
Complementary protection is incorporated into New Zealand law under the Immigration Act as a form of protection supplementary to refugee status - "protected person status". ${ }^{36}$ Section 130 requires a person to be recognised as a protected person under the Convention against Torture and Other Cruel, Inhuman or Degrading Treatment or Punishment ${ }^{37}$ ("the Torture Convention") where the applicant would be "in danger of being subjected to torture if deported from New Zealand". ${ }^{38}$ Section 131 requires that someone be recognised as a protected person under arts 6 and 7 of the International Covenant on Civil and Political Rights (ICCPR) ${ }^{39}$ where there are substantial grounds to believe they would be in danger of "being subjected to arbitrary deprivation of life or cruel treatment" if deported. ${ }^{40}$

Section 130 is unlikely to provide a ground of protection for those displaced by climate change. ${ }^{41}$ The definition of "torture" requires instigation, consent or acquiescence by a public official. ${ }^{42}$ In Teitiota, however, it was considered whether the applicant could gain protection under s 131. The IPT found that protection on the basis of the arbitrary deprivation of life requires an act or omission of the state which threatens an imminent violation of the right. ${ }^{43}$ The Tribunal recognised that states have positive obligations to protect the right to life from known environmental hazards, and that a failure to do so may, in principle, constitute an omission. ${ }^{44}$ However, it was found that the Kiribati Government had fulfilled these obligations by playing an active role in making known the threats posed to its State by climate change. ${ }^{45}$ A subsequent IPT decision has confirmed that to expect PICT governments to mitigate the underlying drivers of climate change, and to equate such an inability with a failure of state protection, would place "an impossible burden on the state". ${ }^{46}$ It was also confirmed that any threat to life as a result of climate change did not meet

36 Doug Tennent and Katy Armstrong Immigration and Refugee Law in New Zealand (2nd ed, Lexis Nexis, Wellington, 2013) at 21.

37 Convention against Torture and Other Cruel, Inhuman or Degrading Treatment or Punishment 1465 UNTS 85 (opened for signature 10 December 1984, entered into force 26 June 1987).

38 Immigration Act 2009, s 130(1).

39 International Covenant on Civil and Political Rights 999 UNTS 171 (opened for signature 16 December 1966, entered into force 23 March 1976).

40 Immigration Act 2009, s 131(1).

$41 A F$ (Kiribati), above n 16, at [78].

42 Convention against Torture and Other Cruel, Inhuman or Degrading Treatment or Punishment, above n 37 , art 1; and Tennent and Armstrong, above n 36, at 329.

$43 A F$ (Kiribati), above n 16, at [85] and [89].

44 At [87].

45 At [88].

46 AC (Tuvalu) [2014] NZIPT 800517 and [2014] NZIPT 800520 at [75]. 
the required threshold to establish imminence. ${ }^{47}$ The applicant was also unable to show that there was a qualifying act by the Kiribati Government which would amount to "cruel treatment". ${ }^{4}$

Therefore, the IPT, High Court and Court of Appeal decisions in Teitiota confirm that the current position in the New Zealand context is that without an added element of human agency, neither refugee nor complementary protection will extend to those who are forced to relocate as a result of climate change.

\section{Humanitarian grounds}

Additional protection on humanitarian grounds exists within the New Zealand legal framework. Pursuant to s 207 of the Immigration Act, the IPT has the discretionary power to overturn a decision for deportation where the applicant does not meet the requirements for refugee or protected person status, but there are "exceptional circumstances of a humanitarian nature that would make it unjust or unduly harsh for the appellant to be deported". 49 The potential of this ground to provide protection to those displaced by climate change has been significantly overstated in recent media coverage of the IPT decision in $A D$ (Tuvalu), which heralded the case in which a Tuvaluan family successfully appealed a decision for their deportation on humanitarian grounds as "the first legal recognition of 'climate refugees"'. ${ }^{50}$ This characterisation is however "wildly off the mark". ${ }^{51}$ While climate change was one of the matters taken into account by the IPT when considering whether humanitarian circumstances existed, ${ }^{52}$ the finding of such circumstances was based for the most part on the fact that deportation in this case would have amounted to an "unusually significant disruption to a dense network of family relationships". ${ }^{53}$ It should also be noted that the applicants brought another case for refugee and protected person status on the basis of the impacts of climate change. This claim was rejected in AC (Tuvalu), a decision confirming the reasoning in Teitiota. ${ }^{54}$

$A D$ (Tuvalu) by no means marks the discovery of a new avenue for protection for those displaced by climate change. Even though evidence of the impacts of climate change may be

$47 A F$ (Kiribati), above n 16, at [91]

48 At [95].

49 Jane McAdam "No 'Climate Refugees' in New Zealand" (13 August 2014) Planet Policy: Brookings Institution <www.brookings.edu>.

50 McAdam, above n 49; and Amy Maas "Tuvalu climate change family win NZ residency appeal" The New Zealand Herald (online ed, Auckland, 3 August 2014).

51 Vernon Rive "'Climate refugees' revisited: a closer look at the Tuvalu decision" (14 August 2014) Vernon Rive: Environmental Barrister <www.vernonrive.co.nz>.

$52 A D$ (Tuvalu), above n 18, at [30].

53 At [31].

54 AC (Tuvalu), above $\mathrm{n} 46$. 
considered as part of the inquiry into whether humanitarian circumstances exist, ${ }^{55}$ humanitarian grounds will only provide protection in unique cases where the stringent test of "exceptional circumstances" is satisfied. ${ }^{56}$ Generally, climate change alone will not be enough to reach this threshold. ${ }^{57}$ As such, Vernon Rive has noted that the decision does not "provide an open ticket for people from all the places that are impacted by climate change" ${ }^{58}$ If anything, it serves to highlight the limits of current legal protection. ${ }^{59}$

\section{B United Nations Framework Convention on Climate Change}

There are also no general obligations on states at international law with regard to climate change displacement. Under the UNFCCC, developed countries are committed to providing assistance to developing countries "in meeting costs of adaptation to those adverse effects [of climate change]". 60 While migration is considered an adaptation measure, this broad commitment is not reinforced by any obligations specifically concerned with migration. ${ }^{61}$

\section{Responsibility to Protect}

It has also been argued that the international community may be subject to an emerging "responsibility to protect" in relation to those who are displaced by natural disasters, such as climate change, where their own governments are unable or unwilling to assist them. ${ }^{62}$ However, while the International Commission on Intervention and State Sovereignty's 2001 Report identified "overwhelming natural or environmental catastrophes" as a possible ground upon which a responsibility to protect might arise, ${ }^{63}$ at the 2005 World Summit the scope of the responsibility was limited to situations of genocide, war crimes, crimes against humanity and ethnic cleansing. ${ }^{64}$ Therefore, although it is possible that a responsibility might arise where the impacts of climate

$55 A D$ (Tuvalu), above n 18 , at [32].

56 Rive, above n 51.

57 Rive, above n 51.

58 Maas, above n 50.

59 McAdam, above n 49.

60 United Nations Framework Convention on Climate Change, above n 15, art 4(4).

61 McLeman, above n 24, at 15.

62 Tyra Saecho "Natural Disasters and the Responsibility to Protect: From Chaos to Clarity" (2007) 32 Brooklyn J Int'l L 663.

63 International Commission on Intervention and State Sovereignty The Responsibility to Protect (December 2001) at 33 .

642005 World Summit Outcome GA Res 60/1, A/Res/60/1 (2005) at [138]. 
change led to a situation in which such crimes are committed, ${ }^{65}$ it is difficult to speak of any existing or emerging responsibility towards those displaced by climate change at the current time.

\section{$D$ Regional Instruments in the Pacific}

Finally, there are no obligations on states at a regional level in the Pacific which address protection of people displaced by climate change. In 2008, the Pacific Islands Forum signed the Niue Declaration in which nations undertook to "encourage the Pacific's Development Partners to increase their technical and financial support for climate change action on adaptation, mitigation and, if necessary, relocation". ${ }^{66}$ This commitment, however, was non-binding and no specific obligations were agreed upon. Subsequently, in the Majuro Declaration of September 2013, the reference to "relocation" was omitted. ${ }^{67}$

It is thus clear that those who are displaced by climate change "fall through the cracks of international refugee and immigration policy". 68

\section{CLIMATE CHANGE DISPLACEMENT IN THE PACIFIC REGION AND IMPLICATIONS FOR NEW ZEALAND}

The issue of the protection deficit at international law for those displaced by climate change is a global one. This article argues, however, that it should be of particular concern to New Zealand as a developed nation in the Pacific - a region often considered "climate change ground zero". ${ }^{6}$

\section{A Climate Change Displacement in the Pacific}

PICTs are on the climate change front line. As low-lying states, they are vulnerable to sea level rise and the increased frequency of extreme sea-level events such as storm surges. ${ }^{70}$ Erosion and flooding pose a significant threat to PICTS, where most human communities and infrastructure are

65 Stuart Ford "Is the Failure to Respond Appropriately to a Natural Disaster a Crime Against Humanity? The Responsibility to Protect and Individual Criminal Responsibility in the Aftermath of Cyclone Nargis" (2010) 38 Denv J Int'l L \& Pol'y 227.

66 Pacific Islands Forum "Forum Leaders endorse the Niue Declaration on Climate Change" (press release, 26 August 2008).

67 Pacific Islands Forum "Majuro Declaration for Climate Leadership" (adopted 5 September 2013, Majuro); and Vernon Rive "Safe Harbours, Closed Borders? New Zealand Legal and Policy Responses to Climate Displacement in the South Pacific" (paper presented to the 2013 IUCN Academy of Environmental Law Annual Colloquium, Waikato University, June 2013) at 5.

68 International Organization for Migration Migration and Climate Change (2008) at 10.

69 McAdam, above n 6, at 2.

70 Intergovernmental Panel on Climate Change "Small Islands" in Climate Change 2014: Impacts, Adaptation, and Vulnerability - Part B: Regional Aspect (Cambridge University Press, Cambridge, 2014) 1613 at 1619. 
located in coastal zones and there are limited internal relocation opportunities. ${ }^{71}$ Salt-water intrusions threaten the contamination of fresh water sources ${ }^{72}$ and the salination of arable soil, which reduces agricultural productivity - the base of PICT economies. ${ }^{73}$ Furthermore, increased ocean acidity leads to the degradation of coral reefs, which play a significant role in reducing foreshore erosion and are critical to the subsistence fisheries and tourism industries. ${ }^{74}$ While much of the discussion of the risks faced by PICTs has focused on that of inundation, the more immediate threat is these slow-onset processes, which will make the land increasingly unsustainable and eventually uninhabitable, "long before complete inundation". ${ }^{75}$ At greatest risk are atolls such as Kiribati, Tokelau, Tuvalu and the Marshall Islands, which are low-lying, with no soils, no surface water, low levels of terrestrial biodiversity, and fragile groundwater systems. ${ }^{76}$

These physical vulnerabilities are further exacerbated by pre-existing development challenges faced by PICTs which make adaptation to changing conditions more difficult. The Stern Review recognised that "climate change ... will have a disproportionately harmful effect on developing countries"77 as a result of "exposure to an already fragile environment, an economic structure that is highly sensitive to an adverse and changing climate, and low incomes [constraining] their ability to adapt". ${ }^{78}$ This is especially true in the case of the Pacific Islands, which are "amongst the most aiddependent and least progressive developing nations in the world". ${ }^{79}$ The Pacific faces challenges including poverty, low GDP, unemployment, pollution, high population growth and over-population in urban areas. ${ }^{80}$ Kiribati's Solicitor-General David Lambourne has noted that "climate change

71 At 1618.

72 At 1622; and John Campbell "Climate Change Migration in the Pacific" (2014) 26 The Contemporary Pacific 1 at 3 .

73 Intergovernmental Panel on Climate Change, above n 70, at 1632; and Campbell, above n 72, at 3.

74 Intergovernmental Panel on Climate Change, above n 70, at 1621.

75 Maxine Burkett, above n 11, at 4 and 5; McAdam, above n 6, at 16; and Kelly Wyett "Escaping a Rising Tide: Sea Level Rise and Migration in Kiribati" (2014) 1 Asia and the Pacific Policy Studies 171 at 172.

76 Campbell, above n 72 , at 4 .

77 Nicholas Stern The Economics of Climate Change: The Stern Review (Cambridge University Press, Cambridge, 2007) at 92.

78 At 93 .

79 Stacey Kwant "The Potential of Pacific Seasonal Workers to Meet New Zealand and Australia's Development Goals for the Pacific Islands" (MA Thesis, Victoria University of Wellington, 2012) at 99.

80 Jane McAdam "Swimming against the Tide: Why a Climate Change Displacement Treaty is Not the Answer" (2011) 23 IJRL 2 at 4; and Wyett, above n 75, at 174. 
overlays [these] pre-existing pressures ... which means that it may provide a 'tipping point' that would not have been reached in its absence" ${ }^{81}$

It is clear that by mid-century, as a result of these vulnerabilities, there will be a large number of people in the Pacific displaced by climate change. While there has been limited work done on quantifying this movement, scenarios developed by University of Waikato researcher John Campbell estimate that between 665,000 and 1.7 million individuals in the Pacific will migrate or be displaced by $2050 .{ }^{82}$ One can also get a sense of the scale of the potential migration flows when considering that it is estimated that by 2050 there will be 320,000 people living on Pacific Island atolls - those areas which are most vulnerable to climate change and from which many people are likely to be displaced. ${ }^{83}$ Numbers likely to be displaced from non-atoll locations will also be significant, and could surpass those from atolls. ${ }^{84}$ While more research is needed to quantify this movement, it is clear that climate change has the potential to cause mass population movements in the Pacific. ${ }^{85}$

\section{B An Imperative for New Zealand Action}

It seems clear that New Zealand is under no legal obligation to respond to climate change displacement in the Pacific. Yet, as one of the developed nations in the region, this impending crisis and the lack of any international response should be of particular concern. There are significant incentives for New Zealand to act.

First, there is a well-documented moral argument for developed nations with high per capita emissions, such as New Zealand, to support the people of developing nations who will suffer disproportionately compared to their contribution to climate change. ${ }^{86}$ PICTs are responsible for only an estimated 0.3 per cent of global emissions ${ }^{87}$ and only 1.84 per cent of Oceania's emissions (the bulk coming from Australia and New Zealand), ${ }^{88}$ but these nations will experience the impacts

81 At 13.

82 John Campbell "Climate Change and Population - Movement in Pacific Island Countries" in Bruce Burson (ed) Climate Change and Migration: South Pacific Perspectives (Institute of Policy Studies, Wellington, 2010) 29 at 38 .

83 Campbell, above n 72 , at 13.

84 At 14.

85 New Zealand Department of Labour Population Movement in the Pacific: A Perspective on Future Prospects (February 2012) at vi.

86 Burkett, above n 11, at 3 .

87 "Echoing the call for swift, concentrated and global action on climate change" (1 April 2014) Secretariat for the Pacific Regional Environment Programme <www.sprep.org>.

88 John Campbell and Jon Barnett Climate Change and Small Island States: Power, Knowledge and the South Pacific (Earthscan, London, 2010) at 10. 
of climate change most severely. Thus, there is a "unique and compelling moral element to [these] migrants' situation", ${ }^{89}$ and a strong moral imperative for a nation with the stated goal of making "its mark as a global citizen" to provide for their protection. ${ }^{90}$

There is also a significant practical incentive for New Zealand to act. The impacts of climate change will increasingly be felt in the Pacific, and as they grow more acute, New Zealand will face increasing pressure for migration opportunities from its vulnerable PICT neighbours. A number of Pacific leaders have identified New Zealand as a country from whom assistance is sought in addressing the challenges of climate change. ${ }^{91}$ New Zealand has a long history of playing an important role in the Pacific, providing support to smaller island states and establishing strong cultural, social and political ties. ${ }^{92}$ There are also significant numbers of Pacific people already settled in New Zealand who retain strong ties to their countries of origin, and whose pre-established communities offer support for future migrants. ${ }^{93} \mathrm{New}$ Zealand is seen as a natural migration destination, and it would "be naïve ... to expect anything other than a significant increase in the numbers of Pacific residents seeking refuge in ... New Zealand". ${ }^{94}$ New Zealand will, whether by choice or not, be on the front line in addressing climate change displacement in the Pacific.

To withhold action is to wait for a humanitarian crisis to occur; a situation which would require significantly higher levels of outward migration, with greater urgency, higher costs and less scope for planning. ${ }^{95}$ It would also give rise to a serious security threat in the region. As conditions become more challenging and resources more scarce, climate change has "the potential to ... lead to considerable instability, disruption and conflict" in the Pacific. ${ }^{96}$ Therefore, while international law does not provide adequate protection to those who will be displaced, "we cannot continue to ignore environmental refugees simply because there is no institutionalised mode of dealing with them". 97 Instead, beginning to address this issue now will lessen the impact and likelihood of a humanitarian

89 Burkett, above n 11, at 3.

90 New Zealand Ministry of Foreign Affairs and Trade Statement of Intent 2014-2018 (June 2014) at 6.

91 Isaac Davison "Sinking Islands Call for NZ action" The New Zealand Herald (online ed, Auckland, 3 September 2013); and Rive, above n 67, at 3.

92 Rive, above n 67, at 1.

93 At 3 .

94 At 8 .

95 Wyett, above n 75, at 174 .

96 Australian Labor Party Our Drowning Neighbours: Labor's Policy Discussion Paper on Climate Change in the Pacific (2006) at 7 .

97 Norman Myers "Environmental Refugees: An Emergent Security Issue" (paper presented to the 13th meeting of the OSCE Economic Forum, Prague, May 2005). 
crisis in the Pacific. The key question, therefore, is what shape a New Zealand policy response should take.

\section{A NEW ZEALAND POLICY RESPONSE}

It is critical that any response to climate change displacement in the Pacific not only provides the opportunity for Pacific peoples to migrate, but that such a response ensures "migration with dignity". ${ }^{98}$ Much of the literature examining climate change displacement has focused on "remedial protection responses", instruments which provide protection once people have been displaced, such as the extension of refugee status and complementary protection measures, at either the international or domestic level. ${ }^{99}$ Such measures, however, are designed to respond only once a humanitarian crisis has occurred and fail to address the scope that exists for pre-emptive action, which may help to avoid a migration crisis occurring, or lessen its impact.

The slow onset nature of climate change impacts provides an opportunity which does not usually exist in other instances of mass displacement to "plan for responses, rather than [rely] on remedial instruments in the case of spontaneous and desperate flight". ${ }^{100}$ There will be significant benefits for both origin and destination communities if the migration of increasing numbers of people from the Pacific can be "managed progressively through a co-ordinated approach" in which Pacific peoples make their own decisions about movement, in their own time. ${ }^{101}$ Kiribati President, Anote Tong, has emphasised: 102

... the relocation of the 100,000 people of Kiribati ... cannot be done overnight. It requires long term forward planning and the sooner we act, the less stressful and the less painful it [will] be for all concerned.

Schemes which work on the model of pre-emptive, voluntary migration have a much higher chance of success than delaying action until the mass resettlement of communities becomes the only option. ${ }^{103}$

98 Office of the President, Republic of Kiribati, above n 10

99 See for example Biermann and Boas, above n 5; Docherty and Giannini, above n 11; and Hodgkinson and others, above $n 11$

100 McAdam, above n 80, at 4

101 Richard Bedford and Charlotte Bedford "International Migration and Climate Change: A Post-Copenhagen Perspective on Options for Kiribati and Tuvalu" in Bruce Burson (ed) Climate Change and Migration: South Pacific Perspectives (Institute of Policy Studies, Wellington, 2010) 89 at 125 and 126.

102 Anote Tong, President of the Republic of Kiribati "Statement by his Excellency Anote Tong President of the Republic of Kiribati" (General Debate of the 63rd Session of the United Nations General Assembly, 25 September 2008).

103 Bedford and Bedford, above n 101, at 125. 


\section{A Migration as a Form of Adaptation}

Pre-emptive, voluntary migration schemes challenge the assumption that migration represents a failure of adaptation and a measure of last resort. ${ }^{104}$ In fact, migration can be an important part of an "integrated adaptation strategy" for communities who must adjust to changing environmental conditions. ${ }^{105}$ Migration can contribute positively to adaptation by building financial, social and human capital, improving the lives of migrants and their home communities. ${ }^{106}$

Migrants who relocate under pre-emptive, voluntary schemes have a far greater chance of successfully settling in New Zealand than forced migrants. They will face lower costs and a lower risk of social dislocation than if they are forced to migrate in an emergency situation. ${ }^{107}$ The gradual settlement of Pacific peoples in New Zealand in a slow but sustained process will also allow communities to become established, and then facilitate future migration. ${ }^{108}$

Pre-emptive, voluntary migration will be beneficial to the communities of origin, helping them to adapt to climate change. Communities receive significant financial benefits through the receipt of remittances - money sent back to home communities by migrants. ${ }^{109}$ Remittances are already an important source of finance for development in the Pacific, for example amounting to 15 per cent of GDP in Kiribati and 40 per cent in Tonga. ${ }^{110}$ Remittances ensure access to basic needs across seasons and during livelihood shocks, and provide added capital to the local economy, which helps communities to adapt. ${ }^{111}$ Secondly, communities of origin receive benefits when migrants return home temporarily, bringing with them new skills and knowledge. ${ }^{112}$ Importantly, pre-emptive migration schemes also relieve population pressures and demands for resources in sending

104 Asian Development Bank, above n 12, at 46; and Jon Barnett and Natasha Chamberlain "Migration as Climate Change Adaptation: Implications for the Pacific" in Bruce Burson (ed) Climate Change and Migration: South Pacific Perspectives (Institute of Policy Studies, Wellington, 2010) 51 at 57.

105 Intergovernmental Panel on Climate Change, above n 2, at 770; and Campbell, above n 72, at 7.

106 Jon Barnett and Michael Webber "Migration as Adaptation: Opportunities and Limits" in Jane McAdam (ed) Climate Change and Displacement: Multidisciplinary Perspectives (Hart Publishing, Oxford, 2012) 37 at 38; and Barnett and Chamberlain, above n 104, at 52.

107 Asian Development Bank, above n 12, at 52.

108 Campbell, above n 82 , at 42 .

109 Intergovernmental Panel on Climate Change, above n 2, at 771; and McAdam, above n 80, at 20.

110 Barnett and Chamberlain, above n 104, at 55.

111 At 44.

112 At 45 . 
countries, and this significantly increases adaptive capacity ${ }^{113}$ allowing those who wish to remain to do so for longer. ${ }^{114}$

There are also clear benefits to New Zealand in implementing pre-emptive, voluntary migration schemes. While the dominant discourse in developed nations around migrants is often negative, there is a significant body of research to show that migrants who move voluntarily are generally hard-working, seeking to maximise incomes, build a life for themselves and send money back to relatives at home. ${ }^{115}$ From a New Zealand perspective, pre-emptive, voluntary migration schemes allow a greater degree of control over the process of migration. Schemes can be developed which will have dual benefits, both for sending communities and New Zealand: there are lower costs and less infrastructure is required than in a situation of mass relocation. ${ }^{116}$

\section{B The Challenges of Pre-emptive Migration Schemes}

In order for implementation to be successful however, the challenges inherent in such schemes must be addressed.

For many of those who choose to relocate to New Zealand, it is likely that migration will be a challenging process. Climate migrants will generally be moving from rural and developing communities, with limited financial resources. They are likely to face challenges in integrating into their new communities. ${ }^{117}$ There is a risk that migrants could be subject to discrimination and that they may be locked into low-wage jobs as a result of low skill levels, or of having skills which are not suited to the New Zealand job market. ${ }^{118}$ This is of particular concern, not only because these factors may affect migrants' abilities to settle and contribute to New Zealand society, but also because if migrants are unable to settle successfully, this may engage New Zealand's legal responsibilities on the international plane. In agreeing to settle climate migrants, New Zealand's obligations are not simply limited to ensuring their "survival and physical security", but also to upholding their civil and political, as well as economic, social and cultural rights. ${ }^{119}$ If migrants do not receive adequate support, this may impair their enjoyment of their rights as minority groups ${ }^{120}$

113 At 45.

114 McAdam, above n 80, at 21; and Rive, above n 67, at 1.

115 Barnett and Webber, above n 106, at 45.

116 Asian Development Bank, above n 12, at 52.

117 Barnett and Webber, above n 106, at 46

118 At 46.

119 Australian Rights and Equal Opportunity Commission Background Paper: Human Rights and Climate Change (2008) at 20.

120 Groups who are "numerically inferior ... in a non-dominant position, whose members ... possess ethnic, religious, or linguistic characteristics differing from those of the rest of the population and show, if only 
to enjoy and take part in cultural life, ${ }^{121}$ as well as their rights to work, to education and to an adequate standard of living. ${ }^{122}$ In order to comply with these positive obligations ${ }^{123}$ and to ensure successful settlement of migrants, New Zealand may need to provide extra support at an individual level, for example assistance with job-seeking, finding housing and developing language skills to help migrants to adjust to life in New Zealand, ${ }^{124}$ and at a community level to facilitate the continuance of social practices. ${ }^{125}$

Communities of origin also face risks with the introduction of migration schemes, primarily the loss of human capital, especially because those who migrate are likely to be more skilled than those who remain. Where the movements of people are large, migration may increase vulnerability to climate change. ${ }^{126}$ For example since the early 1970 s, there has been large-scale migration from Niue, which is in free association with New Zealand (meaning that all Niueans are New Zealand citizens), to the extent that now 80 per cent of the Niuean-born population live in New Zealand. ${ }^{127}$ This has reduced population and resource pressures in Niue, but it has also accentuated market distortions, increased labour demands, increased disputes over land and raised significant concerns about Niue's ability to maintain its cultural identity. ${ }^{128}$ To ensure migration schemes have adaptive benefits for communities of origin, they must not counter the efforts of other adaptation programmes. It is important to try and avoid a "brain drain" with the out-migration of skilled community members. This might involve staggering movement, diversifying the nature of the schemes, facilitating temporary migration, encouraging the temporary return of permanent migrants and encouraging migration from communities not currently benefiting from remittances. ${ }^{129} \mathrm{New}$

implicitly, a sense of solidarity, directed towards preserving their culture, traditions, religion or language": Francesco Capotorti, UN Special Rapporteur Study on the Rights of Persons belonging to Ethnic, Religious and Linguistic Minorities E/CN.4/Sub.2/Rev.1 (1979) at [242].

121 International Covenant on Civil and Political Rights, above n 39, art 27; and International Covenant on Economic, Social and Cultural Rights 993 UNTS 3 (opened for signature 16 December 1966, entered into force 3 January 1976), art 15.

122 International Covenant on Economic, Social and Cultural Rights, above n 121, arts 6, 11 and 13.

123 Sarah Joseph, Jenny Schultz and Melissa Castan The International Covenant on Civil and Political Rights: Cases, Materials and Commentary (2nd ed, Oxford University Press, Oxford, 2004) at 792.

124 Barnett and Webber, above n 106, at 46.

125 Wyett, above n 75, at 181 .

126 Jon Barnett "On the risks of engineering mobility to reduce vulnerability to climate change: insights from a small state" in Kirsten Hastrup and Karen Fog Olwig Climate Change and Human Mobility: Global Challenges to the Social Sciences (Cambridge University Press, Cambridge, 2012) 169 at 171.

127 Barnett, above n 126, at 169 and 175.

128 At 179,180 and 184.

129 Barnett and Webber, n 106, at 47. 
Zealand must also encourage the practice of remittance payments to ensure maximum financial benefit for PICT communities from migration, for example by capping fees to reduce the costs of transfers. ${ }^{130}$

The implementation of migration schemes in response to climate change will also have costs for New Zealand, with an increased burden on finances and infrastructure. From a New Zealand perspective, a balance must be reached between trying to minimise the costs of such schemes, while also ensuring that once a commitment is made to implementation, there is sufficient investment to ensure they are successful. Costs will be reduced in the short term by encouraging migration of skilled migrants and migrants who are able to work or be trained in areas of skill shortage in New Zealand. Long-term costs will be reduced by providing the adequate support to migrants to ensure they are able to settle successfully in New Zealand.

\section{POLICY RECOMMENDATIONS}

This article recommends that a New Zealand approach to addressing climate change displacement in the Pacific should involve the implementation of a range of voluntary, pre-emptive migration schemes, which facilitate mobility in the region for a diverse range of people, while balancing the interests of migrants, PICT communities and New Zealand. These schemes should build upon the pre-existing immigration framework, and include the expansion of permanent and temporary migration schemes, and the implementation of labour-training programmes.

\section{A Permanent Migration Schemes}

One focus of New Zealand policy reform should be on increasing the ability of PICT citizens to gain residency in New Zealand through targeted schemes.

\section{Current scheme - the Pacific Access Category}

New Zealand is unique in already having in place a scheme for permanent migration to New Zealand directed specifically at PICTs - the Pacific Access Category (PAC). The PAC provides for residency for 75 people from Kiribati, 75 from Tuvalu and 250 from Tonga annually. ${ }^{131}$ The scheme was introduced in 2002, and is designed to grant residency to Pacific people who would otherwise not meet the regular requirements ${ }^{132}$ and as a means of assisting these smaller nations. ${ }^{133}$ The scheme replaced the seasonal work arrangements previously in place with Tuvalu and

130 Asian Development Bank, above n 12, at 52.

131 Immigration New Zealand Operational Manual (29 November 2010) at S1.40.1.

132 Charles Stahl and Reginald Appleyard Migration and Development in the Pacific Islands: Lessons from the New Zealand Experience (Australian Agency for International Development, 2007) at 30.

133 Lianne Dalziel "Government Announces Pacific Access Scheme" (press release, 20 December 2001). 
Kiribati. ${ }^{134}$ Applicants are drawn from a ballot and invited to apply for residence. In order to meet conditions for residence, it must be shown that they: ${ }^{135}$

(a) are aged between 18 and 45;

(b) have an offer of employment in New Zealand; 136

(c) meet minimum English language requirements; and

(d) meet health and character requirements for New Zealand residence applications.

The PAC is a traditional migration programme, but in some respects it is already well suited towards being a tool for climate change migration. It is aimed specifically at Pacific Island countries which are particularly vulnerable to climate change, and provides a migration pathway for people who do not meet the regular requirements for residency. ${ }^{137}$ The ballot process means that all migrants have an equal chance of being invited to apply for residence. ${ }^{138}$ Further reform of the scheme would, however, improve its utility as a climate change migration tool. The scheme exists under the Immigration New Zealand Operational Manual (the INZ Operational Manual), ${ }^{139}$ which constitutes "immigration instructions" for the purposes of the Immigration Act, ${ }^{140}$ and as such, the terms of the scheme can be altered upon certification of the Minister. ${ }^{141}$ Legislative change is not required for the necessary reforms to be made.

\section{Options for reform}

The first focus for reform of the PAC should be on incrementally increasing quota numbers and expanding the scheme to other vulnerable PICTs. Quota numbers under the scheme are small. Ongoing population growth in islands such as Kiribati and Tuvalu is going to increase the number of people who may require relocation, and slowing or reversing this population growth will require significant increases in out-migration. ${ }^{142}$ In the case of Tuvalu, because of its small population $(10,000)$, these numbers are relatively low compared to New Zealand's overall residency

134 Dalziel, above n 133.

135 Immigration New Zealand, above n 131, at S1.40.5.

136 A fulltime permanent job, or a full-time job for a term of at least 12 months with an option for further employment: Immigration New Zealand, above n 131, at S1.40.30.

137 Stahl and Appleyard, above n 132, at 30.

138 At iv.

139 Immigration New Zealand, above n 131, at S1.40.

140 Immigration Act 2009, ss 22-25; and "Operational Manual: About this Manual" (25 August 2014) Immigration New Zealand <www.immigration.govt.nz>.

141 Immigration Act 2009, s 22.

142 Bedford and Bedford, above n 101, at 128. 
programme. However, in the case of Kiribati (population 100,000), "reversing population growth ... will be impossible without major increases in out-migration". ${ }^{143}$ Increased quotas under the PAC would be one way of facilitating increased flows of migrants from these vulnerable PICTs.

A second focus for reform should be increased job-seeker support so that those who are selected under the ballot are able to take up their invitations for residency. There is some evidence that those who have been selected under the scheme have had difficulty finding appropriate employment. ${ }^{144}$ While there are already some supports in place for those who are selected under the ballot (for example employment agents in New Zealand who pass on CVs of applicants to prospective New Zealand employers, and the ability to travel to New Zealand on a visitor visa to search for a job), ${ }^{145}$ more could be done to ensure those selected in the ballot are eligible for residence. This could include funding recruitment agents to actively seek out job opportunities for migrants who are unable to find their own employment. It could also include the provision of financial support to help those who need to travel to New Zealand on a visitor visa to search for work.

The scheme's regulatory framework should also be reconsidered. While the scheme's basis in the INZ Operational Manual means that reform of the scheme can be more easily achieved than if parliamentary support was required, it also leaves the PAC, as a unilateral scheme without a legislative basis, vulnerable to abolition or limitation. In order to better secure this migration pathway for climate change migrants, it may be that the scheme itself should be given a legislative basis, or given the status of international legal obligation in the form of bilateral or plurilateral agreements with the Pacific countries of origin.

\section{Limitations of reform}

A key limitation of the scheme, however, is that migration under PAC will not be possible for a large portion of PICT populations who are unskilled, and will not meet the age and language requirements, or will be unable to find a job in New Zealand ${ }^{146}$ - the very people who are most vulnerable to the impacts of climate change. ${ }^{147}$ Therefore, there are significant equity concerns about the scheme. The possibility for reform in this area, however, is likely to be limited. The removal of the requirements under the scheme would be unlikely to be politically viable, as this would involve far greater cost for New Zealand. Migrants arriving without the necessary skills to adjust to life in New Zealand would require far greater settlement support, more akin to that provided to refugees.

143 At 128

144 At 107 and 126.

145 Stahl and Appleyard, above n 132, at 30.

146 Bedford and Bedford, above n 101, at 107.

147 Human Rights and Climate Change HRC Res 10/4, A/HRC/Res/10/4 (2009). 
Another concern about the expansion of the PAC is that in offering permanent migration to PICT community members who are more skilled, and, therefore, likely to play an important part in a community's ability to adapt to changing environmental conditions, there is a risk of reducing the adaptive capacity of communities. ${ }^{148}$ Implementation, therefore, must balance New Zealand's interest in receiving migrants of a particular skill level, and the interests of PICTs in retaining human capital. This will be best achieved by ensuring that increased quota numbers do not exceed a level which is sustainable in terms of communities' adaptive capacities. Migration beyond this level should be facilitated through temporary migration schemes, which guarantee the return of migrants with improved skill sets. Ensuring that communities receive the financial and social benefits of permanent out-migration will also help to mitigate any possible negative effects of the loss of human capital. This can be achieved by better facilitating remittance payments and encouraging permanent migrants to return home temporarily, so that they can contribute their new knowledge and skills and extend the social network of PICT communities. ${ }^{149}$

\section{B Temporary Labour Migration Schemes}

A second strategy for facilitating migration between New Zealand and PICTs is to increase access to temporary migration.

\section{Current scheme - the Recognised Seasonal Employer Scheme}

New Zealand introduced the Recognised Seasonal Employer ("RSE") Scheme in 2007. The Scheme grants migrants temporary visas to work in the horticulture and viticulture industries. Preference is given to workers from Pacific Islands Forum countries, and workers are granted sevenmonth visas (nine months for those from Kiribati and Tuvalu), and they may return if they are recruited again. ${ }^{150}$ To gain entry under the scheme, migrants must show that they have a job offer from an approved employer. ${ }^{151}$ The scheme was designed to solve the shortage of seasonal labour workers in these industries and boost productivity, as well as benefiting temporary workers and their country of origin. It is designed to contribute to New Zealand's goals in the Pacific region regarding "economic development, regional integration and stability". ${ }^{152}$

148 International Organization for Migration, above n 68, at 33; Campbell, above n 82, at 44; and Asian Development Bank, above n 12, at 48.

149 Barnett and Webber, above n 106, at 47.

150 David McKenzie and John Gibson The Development Impact of a Best Practice Seasonal Worker Policy (World Bank Development Research Group, November 2010) at 4.

151 "Recognised Seasonal Employer (RSE) Work Category" (17 October 2013) Immigration New Zealand <www.immigration.govt.nz>.

152 Kwant, above n 79, at 52-53. 
The RSE scheme has been deemed to be "best-practice"153 and in many ways is a suitable climate change migration tool. The scheme provides the opportunity for migration to a wider group of people than those included under the PAC scheme, as it is targeted at unskilled workers. Migrants under the scheme are able to work temporarily abroad, earn an income, up-skill and then return home. ${ }^{154}$ This allows them to remain in their communities for longer than might otherwise have been possible, and enhances the adaptive capacity of communities, as there is no permanent loss of human capital. Migrants will return to their communities of origin, bringing with them new skill sets and financial resources. Indeed, participation in the scheme has raised incomes in both Tonga and Vanuatu, allowed households to accumulate more assets and increased subjective standards of living. ${ }^{155}$ The time spent by migrants in New Zealand also allows them to develop networks, especially with employers, which may provide opportunities for permanent migration in the future, for example under the PAC. Further reform of the scheme would however be desirable. As with the PAC, the RSE scheme exists under the INZ Operational Manual, meaning changes can be made by the minister without the need for legislative reform. ${ }^{156}$

\section{Options for reform}

In the first instance the focus of reform should be on increasing the number of visas on offer. Currently, the number of visas under the scheme is capped at 9,000. ${ }^{157}$ The horticulture and viticulture industry has been lobbying for increases to the cap, with industry groups saying that the scheme underpins the growth in the sector. ${ }^{158}$ Moreover, the horticulture and viticulture industry is forecasting employment growth of over 3,000 jobs in the next financial year, ${ }^{159}$ and a recent paper by the Ministry of Primary Industries has predicted an extra 7,800 workers will be needed by 2025. ${ }^{160}$ This suggests the capacity for increased quotas. Similar schemes could also be introduced in other growth industries, using the model of the RSE scheme, to increase the temporary migration flow from PICTs.

153 McKenzie and Gibson, above n 150, at 21.

154 McAdam, above n 6, at 31.

155 McKenzie and Gibson, above n 150, at 21.

156 Immigration New Zealand, above n 131, at WH1.

157 Paula Bennett and Michael Woodhouse "Boost for Horticulture and Viticulture Industry" (press release, 22 July 2014).

158 Bennett and Woodhouse, above n 157.

159 Bennett and Woodhouse, above n 157.

160 Lydia Van Kempen "Govt lifts seasonal employer scheme cap" Otago Daily Times (online ed, Dunedin, 23 July 2014). 
Secondly, there is the capacity for Immigration New Zealand ("INZ") to set up better linkages between the RSE and PAC schemes. ${ }^{161}$ There are some employers under the RSE scheme who have looked to support their workers who subsequently get balloted under the PAC by providing them with offers for continuing employment in the horticulture industry, in jobs where their skills are needed through the year. ${ }^{162}$ This enables migrants to experience life in New Zealand before applying for permanent residency, and helps them meet the PAC employment requirements. From a New Zealand perspective, it is also beneficial to have migrants applying for permanent migration who have already spent time in New Zealand, are more familiar with the culture and are likely already to have support networks in New Zealand. Immigration New Zealand could play an active role in encouraging these links. ${ }^{163}$ This could involve ensuring that all RSE employers and employees are aware of, and have access to, information about the PAC, and seeking out employers under the RSE scheme who may have capacity to take on workers not only seasonally, but in the long term also. Additionally, a separate PAC access category could be created under the INZ Operational Manual for those who are already in New Zealand or have already worked in New Zealand temporarily to increase their chance of being selected in the ballot.

As with the PAC, because the RSE scheme exists under the INZ Operational Manual, there may be an interest in achieving greater protection for this pathway by giving it a legislative basis or establishing its terms through international agreement. However, this may be less viable than in the case of the PAC. Because the scheme is designed to respond to labour shortages, it may be harder to predict the future capacity of the scheme, and it is likely the Government would want to retain greater control of its terms.

\section{Limitations of reform}

One concern with the expansion of such a scheme is that it does not deal with long-term migration pressures. In a strict sense this is true. However, relocation is "not simply a material infrastructure process ... it is also a social process". ${ }^{164}$ Many people do not want to migrate, or may not have the resources to do so permanently. ${ }^{165}$ Temporary schemes offer these people another tool for in-situ adaptation. Secondly, temporary schemes allow greater migration flows while having less of a "brain drain" effect than permanent migration schemes, which helps to ensure that out-

161 Bedford and Bedford, above n 101, at 127.

162 At 126.

163 At 126

164 Marianne Elliot and David Fagan "From Community to Copenhagen: Civil Society Action on Climate Change in the Pacific" in Bruce Burson (ed) Climate Change and Migration: South Pacific Perspectives (Institute of Policy Studies, Wellington, 2010) 61 at 78

165 McAdam, above n 80, at 21; and Rive, above n 67, at 1. 
migration does not counteract other adaptive benefits. ${ }^{166}$ Finally, it is also clear that temporary schemes such as this do help to address long-term migration concerns. They allow migrants to develop networks and adapt to the culture in New Zealand, making future permanent migration a greater possibility. ${ }^{167}$

Another potential criticism of expansion of the scheme is that while the RSE is presented as being a "triple-win", there is also an argument that the biggest beneficiary is New Zealand, while migrants are locked into a low-wage, manual strata of the economy. While the scheme was shown to increase household incomes in PICTs, migrants were earning relatively low wages. The median after-tax income in New Zealand reported by seasonal migrants surveyed in a 2010 study was $\$ 12,000 .{ }^{168}$ After accounting for costs, Tongan workers on average remitted or brought back with them $\$ 5,500 .{ }^{169}$ A similar critique could be made of the PAC scheme: that without greater social, economic and educative support within these programmes, Pacific peoples will face a life with little opportunity for growth and few choices in New Zealand.

\section{Labour-Training Migration Pathways}

This article's final policy recommendation is the introduction of labour-training schemes, in which migrants are trained and employed in skilled occupations in shortage in New Zealand.

\section{The Australian model - Kiribati Australia Nursing Initiative}

A model for this exists in Queensland. The Australian Government introduced the "Kiribati Australia Nursing Initiative" (KANI) in 2006, a programme funded through the Australian Agency for International Development (AusAID). ${ }^{170}$ Through the initiative, which is designed to address climate change imperatives, rapid population growth and youth unemployment, and diversify the remittance base, i-Kiribati school graduates are awarded scholarships to train as nurses at Griffith University, Brisbane. ${ }^{171}$ Once their training is complete, they are able to seek employment in Australia, return to Kiribati, or use their skills to qualify for skilled migration in other countries. ${ }^{172}$

166 Barnett and Webber, above n 106, at 47

167 McAdam, above n 80, at 10.

168 McKenzie and Gibson, above n 150, at 15.

169 At 15 .

170 "Kiribati: Kiribati Australia Nursing Initiative" (24 January 2014) Australian Government: Department of Foreign Affairs and Trade <www.dfat.gov.au>.

171 Lea Shaw, Murray Edwards and Akka Rimon KANI Independent Review: Review Report (Australian Department of Foreign Affairs and Trade, April 2013, updated February 2014) at 5.

172 Lara O'Brien "'Migrating with Dignity": A Study of the Kiribati Australia Nursing Initiative (KANI)" (MA Thesis, University of Kansas, 2013) at 60. 
Where students choose to remain and work in Australia, there is no automatic granting of residency or citizenship; instead they must apply for an employer-sponsored visa. ${ }^{173}$

The 2013 Independent Review of the KANI described it as an "innovative model for 'doing development' in small, environmentally fragile Pacific island countries", and found that it "remains strongly relevant to the sustainable development needs of Kiribati and to its adaptation policy of 'migration with dignity' to address serious climate change imperatives". ${ }^{174}$ The review did note, however, that the costs of the scheme were relatively high for the developmental benefits. ${ }^{175}$

\section{New Zealand implementation}

New Zealand could introduce a similar scheme under the INZ Operational Manual, aimed at vulnerable PICTs such as Tuvalu and Kiribati, and designed to fill skill shortages in New Zealand. Long-term skill shortages identified by INZ which could be suitable for inclusion in such schemes include nursing, physiotherapy, radiography, agriculture and forestry, and surveying. ${ }^{176}$ The scheme would likely be most effective if it was implemented in areas such as nursing where there is also a skill shortage in PICTs. ${ }^{177}$

The implementation of a labour-training scheme would provide another migration pathway and would diversify the range of people in PICTs for whom migration is available as an adaptive response. Migration under a labour-training scheme avoids concerns about locking migrants into low-wage jobs, and plays an active role in up-skilling participants. It would result in a diversification of the source of remittances being sent back to their home countries, which helps to ensure that there is a continual flow of remittances back to PICTs, even if there are livelihood shocks in New Zealand. It is also likely that the remittances paid would be higher under such a scheme, as migrants will be working in skilled occupations which are more highly paid. Finally, there are significant benefits to New Zealand in being able to target migration towards areas of labour shortage.

\section{Ensuring success of the scheme}

For the scheme to be a success, however, there needs to be consideration of the tension identified by the Australian review of the KANI which exists between ensuring that the scheme has development benefits for migrants and PICT communities, and the cost implications for New

173 At 121.

174 Shaw, Edwards and Rimon, above n 171, at 11.

175 At 11

176 "Long Term Skill Shortage List" (24 March 2014) Immigration New Zealand <www.immigration.govt.nz>.

177 Joel Negin "Australia and New Zealand's Contribution to Pacific Island Health Worker Brain Drain" (2008) 32 Australian and New Zealand Journal of Public Health 507 at 507. 
Zealand. A labour-training migration scheme has a high cost, especially in comparison to the PAC and the RSE schemes. These costs can be offset to some extent by having migrants contribute to the workforce in areas of skill shortage in New Zealand after they complete their training, which will simultaneously reduce population pressures and increase remittances for communities of origin. However, there are competing concerns: such schemes run the risk of reducing the adaptive capacity of PICT communities through the "brain drain" that may be effected by enabling high-achieving school leavers to emigrate, and there would also be adaptation benefits to PICT communities if migrants return after completing their training and contribute to the health sector in the Pacific Islands.

There are a number of options for achieving an acceptable balance between the cost burden and adaptive benefits. It may be that a scheme would only be financially viable if trainees were under a contractual obligation to work for a set period in New Zealand after graduation. It may also be the case that in order to effectively counter skill shortages in New Zealand, migrants will need to be encouraged or required to live and work in smaller urban centres, rather than in the major cities. It should be noted, though, that migrants will be more likely to settle successfully in larger urban centres, where community support networks are already established.

In order to maximise the adaptive benefits for communities, and to try and avoid the negative effects of the loss of human capital, there could be a condition on participants who remain in New Zealand to return to their countries of origin periodically and volunteer their skills. However, studies of the KANI suggest that a strict requirement may not be necessary - participants felt it was important that they return as regularly as possible, contribute their skills and send money back to their home communities. ${ }^{178}$

In order to ensure the scheme works successfully as a migration pathway, it should also provide greater job-seeking and residency support than the Australian scheme does. The programme should provide the option for trainees to be given a work placement once they have completed their studies, rather than leaving them to seek their own jobs, as is required under the Australian model. This will provide greater security for participants in the programme, who may find job seeking in the New Zealand market difficult, despite having earned the requisite qualifications. The scheme should also provide an automatic granting of residency to participants once they have completed their training (if they wish to stay in New Zealand), rather than requiring them to find work before this is provided. Again, this would offer migrants security and certainty, and reflect a commitment on New Zealand's behalf for the scheme to work not only as a training scheme, but also as a migration pathway.

178 O'Brien, above n 172, at 119 and 125 . 


\section{CONCLUSION}

It is clear that international law provides insufficient protection to the millions of people worldwide who are likely to be displaced by the impacts of climate change. This is of particular concern to New Zealand. The Pacific Region is one of the most vulnerable in the world to the effects of climate change and is likely to experience high levels of out-migration. As a result, New Zealand will face increasing migration pressure from neighbouring PICTs as the situation nears crisis point.

A New Zealand policy response is required to address this concern of mounting migration pressures and the risk of a possible humanitarian disaster in the Pacific. This article has argued that the most effective way of achieving this is through pre-emptive, voluntary migration schemes which facilitate movement between PICTs and New Zealand. Possible measures discussed include extending the Pacific Access Category and the Recognised Seasonal Employer Scheme, as well as introducing labour-training migration schemes.

These initiatives allow migration to be used as a tool of adaptation for migrants and their communities, and allow for New Zealand to plan and manage migration, which will not be possible if migration occurs during a full-scale humanitarian crisis. These schemes will help to ensure that where relocation is necessary, Pacific peoples will be able to migrate with dignity. 
(2015) 46 VUWLR 